\title{
Degradation of 2,4,6-trichlorophenol by a specialized organism and by indigenous soil microflora: bioaugmentation and self-remediability for soil restoration
}

\author{
V. Andreoni, G. Baggi, M. Colombo, L. Cavalca, M. Zangrossi and S. Bernasconi ${ }^{1}$ \\ Department of Food Science and Microbiology, and ${ }^{1}$ Department of Organic and Industrial Chemistry, Università di \\ Milano, Milan, Italy
}

1777/98: received and accepted 5 May 1998

V. ANDREONI, G. BAGGI, M. COLOMBO, L. CAVALCA, M. ZANGROSSI AND S. BERNASCONI. 1998. A selected mixed culture and a strain of Alcaligenes eutrophus TCP were able to totally degrade 2,4,6-TCP with stoichiometric release of $\mathrm{Cl}^{-}$. In cultures of Alc. eutrophus TCP, a dioxygenated dichlorinated metabolite was detected after $48 \mathrm{~h}$ of incubation. Experiments conducted with soil microcosms gave evidence that: the degradative process had a biotic nature and was accompanied by microbial growth; the soil used presented an intrinsic degradative capacity versus 2,4,6-TCP ; the specialized organism used as inoculum was effective in degrading 2,4,6-TCP in a short time. These results could be utilized for the adoption of appropriate remediation techniques for contaminated soil.

\section{INTRODUCTION}

Chlorophenols (CPs), widely used as preservatives for different goods, anti-mildew agents, disinfectants and fungicides (Rao 1978; Sittig 1981), can be formed during the chlorination of waste waters, and are often by-products of the breakdown of pesticides and chlorinated aromatic compounds (Pritchard et al. 1987). These substances, which are carcinogenic and can condense to chlorodibenzodioxins, are extremely toxic and hazardous to the environment (Rochkind et al. 1986). They are included in the US Environmental Agency Priority Pollutant Lists (Anon. 1987). In particular, 2,4,6-trichlorophenol (2,4,6-TCP), which is a precursor for the synthesis of 2,3,4,6-tetrachlorophenol, pentachlorophenol (PCP) and fungicide prochloraz, is detected in large amounts in the environment as it is derived as an intermediate from the breakdown of prochloraz (Bock et al. 1996) and is found as a major component of kraft paper mill effluents (Huynh $e t$ al. 1985).

The microbial degradation of CPs, which may be abiotically degraded through hydrolysis and photolysis (Hwang et al. 1986), has been studied with mixed and pure microbial cultures; under aerobiosis, the metabolic pathway of CPs proceeds through the formation of chlorocatechols for monoand dichlorophenols, and chlorohydroquinones for highly

Correspondence to: Prof. Grazia Baggi, Department of Food Science and Microbiology, Università di Milano, Via Celoria 2, 20133 Milan, Italy (e-mail: G.Baggi@imiucca.csi.unimi.it). chlorinated phenols (Steiert and Crawford 1986; Li et al. 1991; Kiyohara et al. 1992; Wieser et al. 1994; Fava et al. 1995; Tomasi et al. 1995 ; Bock et al. 1996; Koh et al. 1997). Under anaerobic conditions, CPs, independently from the substitution grade, are often reductively dechlorinated up to phenol in fresh water sediments and by microbial consortia under sulphate-reducing and methanogenic conditions (Zhang and Wiegel 1990; Häggblom and Young 1990; Turner Togna et al. 1995); few pure cultures have been shown to degrade CPs anaerobically (Mohn and Kennedy 1992; Utkin et al. 1995 ; Christiansen and Ahring 1996).

Here, the aerobic degradation of 2,4,6-TCP in batch by a mixed culture and a pure strain of Alcaligenes eutrophus TCP is reported. In addition, experiments with soil microcosms were performed to evaluate whether the micro-organism isolated, able to degrade in vitro 2,4,6-TCP, should be used as inoculum to remediate soils contaminated by this specific pollutant.

\section{MATERIALS AND METHODS}

\section{Enrichment cultures}

A mixed culture able to grow on 2,4,6-TCP supplied as the sole carbon and energy source in a mineral medium (MM) was selected by enrichment techniques using as inoculum activated sludges of a waste-water plant. The composition of 
MM was $\left(1^{-1}\right): \mathrm{Na}_{2} \mathrm{HPO}_{4}, 7 \mathrm{~g} ; \mathrm{KH}_{2} \mathrm{PO}_{4}, 3 \mathrm{~g} ;\left(\mathrm{NH}_{4}\right)_{2} \mathrm{SO}_{4}, 0 \cdot 8 \mathrm{~g}$. The $\mathrm{pH}$ was adjusted to $7 \cdot 0$, the medium was autoclaved and then $2.5 \mathrm{ml}$ of $1 \mathrm{~mol} \mathrm{l}^{-1} \mathrm{MgSO}_{4}, 2.5 \mathrm{ml}$ of $36 \mathrm{mmol} \mathrm{l}^{-1}$ $\mathrm{FeSO}_{4} .7 \mathrm{H}_{2} \mathrm{O}$, and $2.5 \mathrm{ml}$ of a trace element solution, were added (Maniatis et al. 1989).

2,4,6-TCP was added to MM medium at the required concentration from a stock solution $(5 \% \mathrm{w} / \mathrm{v})$ in acetone. Other soluble organic substrates (phenol, glutamate etc.) were used as carbon source at $0 \cdot 02 \%(\mathrm{w} / \mathrm{v})$.

\section{Isolation and maintenance of 2,4,6-TCP degrading micro-organism}

From the selected mixed culture, a microbial strain was isolated in the presence of $200 \mathrm{mg}^{-1} 2,4,6$-TCP as the only carbon and energy source. The strain was maintained through subsequent transfers in MM with $300 \mathrm{mg}^{-1}$ 2,4,6-TCP added and frequently checked for purity by plating in Plate Count Agar (PCA) (Difco).

\section{Phenotypic and molecular characterization of the bacterial strain}

The phenotype of the strain was characterized by standardized procedures (Gram stain, mobility, etc) (Doetsch 1981) and by the Biolog GN identification test (Biolog Inc., Hayward, CA, USA).

The characterization at molecular level was performed by amplified ribosomal DNA restriction analysis (ARDRA). The restriction map of the present strain was evaluated in relation to those of Alc. eutrophus ATCC 17697 retrieved from GenBank (accession number : m32021) and performed by Webcutter $^{\mathcal{O}}$ (Max Heim, 1995, http://www.medkem.gu.se/ cutter), Alc. eutrophus JMP 134 and Comamonas acidovorans DSM 8370 . Template DNA $(5 \mu \mathrm{l})$ prepared by Chelex ${ }^{\circledR} 100$ (Biorad) boiling lysis of cell suspension (De Lamballerie et al. 1992), was used to perform PCR amplification in $50 \mu \mathrm{l}$ reaction volume. The mix was prepared with polymerase reaction buffer $\left(10 \mathrm{mmol}^{-1}\right.$ Tris-Cl $\left(\mathrm{pH} 8 \cdot 3 ; 25^{\circ} \mathrm{C}\right) ; 50$ $\mathrm{mmol}^{-1} \mathrm{KCl} ; 1.5 \mathrm{mmol} \mathrm{l}^{-1} \mathrm{MgCl}_{2} ; 20 \mu \mathrm{mol} \mathrm{l}^{-1}$ (each) dATP, dCTP, dTTP, dGTO; $0 \cdot 2 \mu \mathrm{mol}^{-1}$ each of $16 \mathrm{~S}$ rRNA universal primer, placed in positions 27 forward and 1495 reverse (Weisburg et al. 1991), and 1.25 U of Taq polymerase (Promega). PCR amplifications were performed using a thermal cycler (Perkin Elmer GeneAmp PCR System 2400 ) with the following temperature profile: five cycles of denaturation $\left(1 \mathrm{~min}\right.$ at $\left.94^{\circ} \mathrm{C}\right)$, annealing $\left(45 \mathrm{~s}\right.$ at $\left.50^{\circ} \mathrm{C}\right)$, and extension $\left(1 \mathrm{~min}\right.$ at $\left.72^{\circ} \mathrm{C}\right) ; 35$ cycles of denaturation $(40 \mathrm{~s}$ at $\left.94^{\circ} \mathrm{C}\right)$, annealing $\left(45 \mathrm{~s}\right.$ at $\left.55^{\circ} \mathrm{C}\right)$, extension $\left(1 \mathrm{~min}\right.$ at $\left.72^{\circ} \mathrm{C}\right)$; and final extension at $72^{\circ} \mathrm{C}$ for $7 \mathrm{~min}$. Aliquots $(8 \mu \mathrm{l})$ of PCR products were digested with $10 \mathrm{U}$ of restriction endonuclease in $10 \mu \mathrm{l}$ of reaction volumes using the manufacturer's recommended buffer and temperature. The following restric- tion endonucleases (Pharmacia Biotech) were used: AluI, EcoRI, HhaI, HpaII and RsaI. Restricted DNA was analysed by horizontal electrophoresis in 3\% agarose gel (Pharmacia), carried out at $80 \mathrm{~V}$ for $3 \mathrm{~h}$ with $11 \times 13 \mathrm{~cm}$ gels (Easy-Cast B2, Owl Scientific Inc., Woburn, MA, USA).

Similarities between each pair of strains were estimated from the proportion of shared restriction fragments to the total number of fragments identified for all strains, and examined using Jaccard's coefficient (Sokal and Michener 1958). A dendrogram was constructed from the similarity matrix by the unweighted pair group method with arithmetic mean (UPGMA) (Sneath and Sokal 1973) using an NTSYS-pc analysis package (Rohlf 1987).

\section{Soil characteristics}

The soil for microcosms was kindly provided by CNR-Pisa and, in the last 20 years, had not been treated with pesticides. It was characterized as a lime clay soil with a low organic content (1.6\%), CEC (12.4 meq $\left.100 \mathrm{~g}^{-1}\right), \mathrm{pH}\left(\mathrm{H}_{2} \mathrm{O}\right)(8 \cdot 2)$. The soil contained $1.9 \times 10^{7}$ colony forming units $(\mathrm{cfu}) \mathrm{g}^{-1}$ dry soil as enumerated on PCA. Soil $\mathrm{pH}$ was not adjusted and additional nutrients were not used. The soil was stored at approximately $5{ }^{\circ} \mathrm{C}$ until used.

\section{Soil microcosms}

Laboratory microcosms were prepared in triplicate, placing $10 \mathrm{~g}$ of air-dried soil into a $50 \mathrm{ml}$ beaker and adjusting the soil moisture content to $60-80 \%$ of field capacity with distilled deionized water. The beakers, covered with aluminium foil to minimize water loss and contamination, were conditioned for $5 \mathrm{~d}$ at $30^{\circ} \mathrm{C}$ before adding $2,4,6-\mathrm{TCP}$ at $250 \mathrm{mg} \mathrm{kg}^{-1}$ soil from a stock solution. Each experiment consisted of four sample sets : autoclaved soil (AS), autoclaved soil inoculated with the microbial strain selected (AIS), soil (S), and inoculated soil (IS). For AS and AIS microcosms, the soil was autoclaved three times at $121^{\circ} \mathrm{C}$ for $20 \mathrm{~min}$ at $24 \mathrm{~h}$ intervals. For $\mathrm{S}$ and IS microcosms, the soil was used directly.

For microcosm inoculation, the microbial strain was grown at $30^{\circ} \mathrm{C}$ on a shaker in MM with added 2,4,6-TCP. When the culture reached the late logarithmic phase of growth, the cells were collected by centrifugation at $12000 \mathrm{~g}$ for $20 \mathrm{~min}$ at $4{ }^{\circ} \mathrm{C}$, washed with $0 \cdot 1 \mathrm{~mol}$ phosphate buffer $(\mathrm{pH} 7 \cdot 0)$ and suspended in the same buffer to obtain a cell suspension of approximately $8.0 \times 10^{7}-4.0 \times 10^{9} \mathrm{cfu} \mathrm{ml}^{-1}$. When required, $1 \mathrm{ml}$ of cell suspension at low or high density was added as inoculum to each microcosm and mixed thoroughly with the soil.

The beakers were incubated in the dark at $30^{\circ} \mathrm{C}$, checking the moisture content every $7 \mathrm{~d}$. In some cases, $500 \mathrm{mg}$ 2,4,6TCP $\mathrm{kg}^{-1}$ soil were added after $2 \mathrm{~d}$ of incubation.

For determining 2,4,6-TCP loss and bacterial growth, soil 
microcosms were analysed on days $0,1,2$ and 5. 2,4,6-TCP concentration was determined as the quantity of compound present that was water-extractable (WSF) per unit of the soil according to Dasappa and Loehr (1991). The beaker contents were placed in a $300 \mathrm{ml}$ sterile flask containing $200 \mathrm{ml}$ of sterile deionized water, and mixed for $1 \mathrm{~h}$ on a rotary shaker $(250 \mathrm{~g})$ at $30^{\circ} \mathrm{C}$. After $30 \mathrm{~min}$ sedimentation, an aliquot of the supernatant fluid was diluted $(1: 10)$ in tubes containing $9 \mathrm{ml}$ of sterile water, and all dilutions were then plated in duplicate into PCA. The inoculated plates were incubated at $30^{\circ} \mathrm{C}$ for $5 \mathrm{~d}$ and then counted. The remaining supernatant fluid, after centrifuging at $10000 \mathrm{~g}$ for $30 \mathrm{~min}$, was filtered $(0.45 \mu \mathrm{m})$ and stored at $4{ }^{\circ} \mathrm{C}$.

\section{Isolation and characterization of the 2,4,6-TCP metabolite in batch experiments}

Alcaligenes eutrophus TCP was incubated at $30^{\circ} \mathrm{C}$ in Erlenmeyer flasks containing MM with $200 \mathrm{mg} \mathrm{l}^{-1} 2,4,6-\mathrm{TCP}$ added. After $48 \mathrm{~h}$ of incubation, the contents of the flasks were collected and centrifuged at $10000 \mathrm{~g}$. The supernatant fluid was extracted with ethyl acetate; the organic layer was dried over $\mathrm{MgSO}_{4}$ and evaporated to dryness in a rotary evaporator. The residue was analysed by gas chromatography-mass spectrometry (GC-MS).

\section{Analytical procedures}

The decrease of 2,4,6-TCP content in batch experiments was determined by high performance liquid chromatography (HPLC), directly injecting the supernatant fluid obtained from samples of the cultures previously centrifuged at $10000 \mathrm{~g}$ for $20 \mathrm{~min}$ to separate the cells and filtered $(0 \cdot 45 \mu \mathrm{m})$.

Reversed-phase HPLC was carried out using a Jasco instrument (LG 980-02 Ternary gradient Unit) with UVVIS detector (UV-975 Intelligent Jasco, Tokyo, Japan). A Spherisorb ODS 2-04-0525 RP 18 column was used for quantification of 2,4,6-TCP in batch cultures and a Merck Lichrosorb RP8 column in microcosm experiments.

Gas chromatographic analyses were carried out using a Dani (Monza, Italy) 86.10 gas-chromatograph, linked to a Hewlett-Packard (Palo Alto, CA, USA) HP 3396 A integrator, equipped with a fused silica capillary column WCOTCP-Sil 5-CB Chrompack (4330 EA, Middleburg, The Netherlands) $(25 \mathrm{~m} \times 0.32 \mathrm{~mm}$ internal diameter, film thickness $0 \cdot 11 \mu \mathrm{m})$, carrier $\mathrm{H}_{2}\left(0.5 \mathrm{~kg} \mathrm{~cm}^{-2}\right)$, split flow $90 \mathrm{ml}$ $\min ^{-1}$, injection temperature $150^{\circ} \mathrm{C}$, detection temperature $200^{\circ} \mathrm{C}$, initial oven temperature $70^{\circ} \mathrm{C}(4 \mathrm{~min})$, temperature increase $10^{\circ} \mathrm{C} \mathrm{min}{ }^{-1}$, final isotherm $130^{\circ} \mathrm{C}$.

GC-MS data were obtained with a Dani 3800 gas chromatograph connected to a VG-7070 EQ mass spectrometer (the same column was used).

Chloride anion release was determined turbidimetrically at
$460 \mathrm{~nm}$ by the mercury (II) thiocyanate method (Florence and Farrar 1971).

\section{Chemicals}

2,4,6-TCP was from Aldrich Chemical Co. The other chemicals were of the highest grade commercially available.

\section{RESULTS}

\section{Degradation of $2,4,6-\mathrm{TCP}$ by mixed culture}

The selected enrichment culture rapidly degraded $200 \mathrm{mg} \mathrm{l}^{-1}$ 2,4,6-TCP with stoichiometric release of chloride when supplied both as the only carbon source and in the presence of other organic substrates (phenol, benzoate, glutamate $0 \cdot 02 \%$ ). The 2,4,6-TCP degradation rate was markedly higher in the presence of phenol or glutamate (Fig. 1).

\section{Isolation and identification of a 2,4,6-TCP-degrading micro-organism}

From the selected mixed culture, a Gram-negative bacterium capable of growing on 2,4,6-TCP as the sole carbon and energy source was isolated. The strain was first identified as belonging to Alcaligenes eutrophus with a similarity of $62 \%$, according to the biolog GN test. Its molecular characterization was consistent with this phenotypic identification. The dendrogram from the similarity matrix built on ARDRA profiles (data not shown) grouped the micro-organism with Alc. eutrophus strains (Fig. 2). The sequence analysis of the $16 \mathrm{~S}$ rRNA gene should confirm this phylogenetic position.

\section{Degradation of 2,4,6-TCP in batch cultures and in soil microcosms}

Alcaligenes eutrophus TCP was able to degrade $300 \mathrm{mg}^{-1}$ 2,4,6-TCP with stoichiometric release of chloride in $48 \mathrm{~h}$; $500 \mathrm{mg} \mathrm{l}^{-1} 2,4,6$-TCP was totally degraded in $96 \mathrm{~h}$. Higher $2,4,6$-TCP concentrations $\left(700 \mathrm{mg} \mathrm{l}^{-1}\right)$ were not degraded at all. Five additions of 2,4,6-TCP were completely degraded in $14 \mathrm{~d}$ with stoichiometric release of chloride (Fig. 3).

The strain also grew on phenol $(0.5 \%)$ but did not utilize for growth other CPs tested (2-, 3- and 4- chlorophenol, 2,4-, 2,6-, 3,4- and 3,5-dichlorophenol, 2,3,5-, 2,3,6- and 2,4,5trichlorophenol).

A metabolite was isolated from Alc. eutrophus TCP cultures, after $48 \mathrm{~h}$ of incubation, whose mass spectrum gave PM 178, corresponding to the compound $\mathrm{C}_{6} \mathrm{H}_{4} \mathrm{Cl}_{2} \mathrm{O}_{2}$ (Fig. 4), deriving from the substitution of a chlorine atom with a hydroxyl group.

2,4,6-TCP was completely degraded in all monitored microcosms, except in the autoclaved soil (AS) used as 


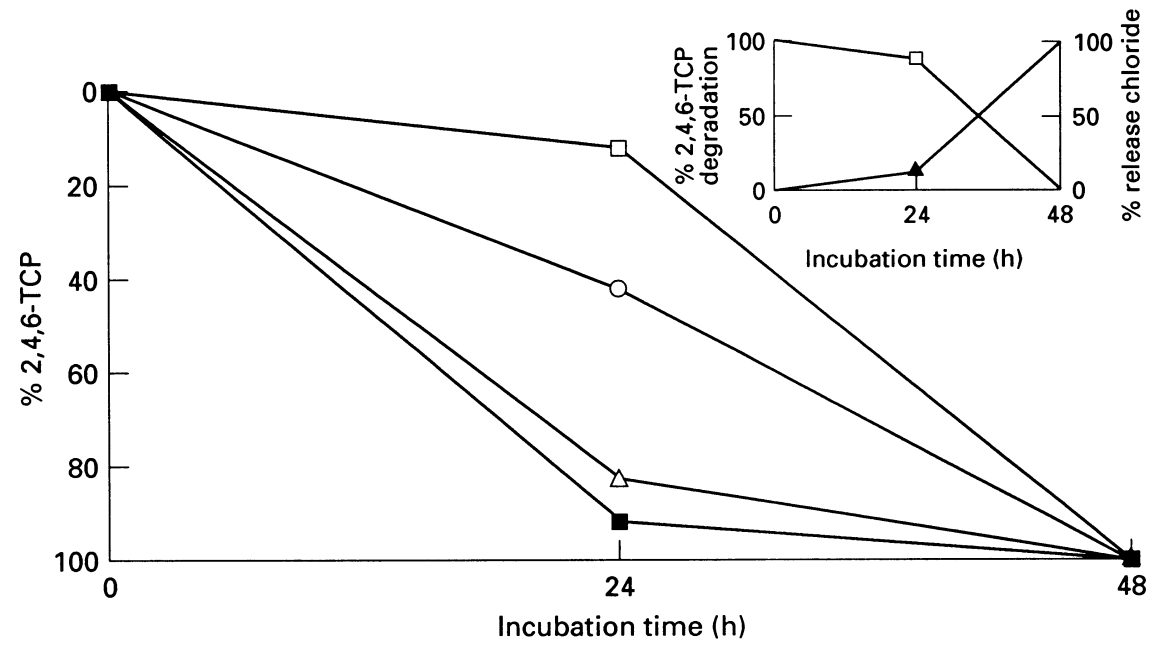

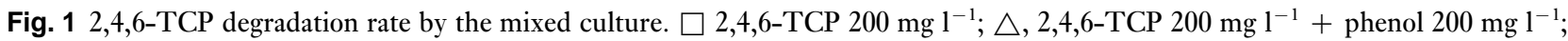
○, 2,4,6-TCP $200 \mathrm{mg} \mathrm{l}^{-1}+\mathrm{Na}$ benzoate $200 \mathrm{mg} \mathrm{l}^{-1} ; \mathbf{\square}, 2,4,6-\mathrm{TCP} 200 \mathrm{mg} \mathrm{l}^{-1}+$ glutamate $200 \mathrm{mg} \mathrm{l}^{-1} ; \mathbf{\Delta}$, chloride

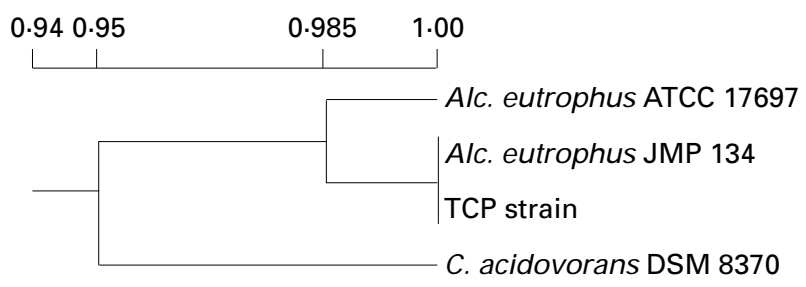

Fig. 2 Phylogeny of Alcaligenes eutrophus strains ATCC 17697 and JMP 134, Comamonas acidovorans DSM 8370 and the studied TCP strain based on $16 \mathrm{~S}$ rDNA genotypes characterized by PCR-RFLP analysis. The upper axis indicates genetic similarity

control. The degradation rate was higher when the soil microcosm was inoculated with Alc. eutrophus TCP (IS) (100\% in $24 \mathrm{~h}$ ). A further addition of $500 \mathrm{mg} \mathrm{kg}^{-1} 2,4,6-\mathrm{TCP}$ to

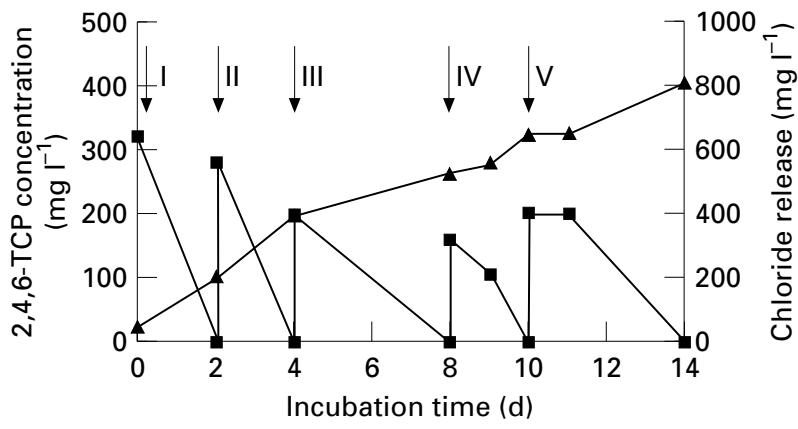

Fig. 3 2,4,6-TCP degradation rate by Alcaligenes eutrophus TCP. $\boldsymbol{\square}, 2,4,6-\mathrm{TCP}$ concentration; $\boldsymbol{\Delta}$, chloride concentration. Arrows indicate successive 2,4,6-TCP additions (I, II $=300 \mathrm{mg} \mathrm{l}^{-1}$; III, IV, $\mathrm{V}=200 \mathrm{mg} \mathrm{l}^{-1}$ ) the microcosms on the second day of incubation was totally degraded in $72 \mathrm{~h}$ in the inoculated microcosm (IS). The control, consisting of autoclaved soil inoculated with Alc. eutrophus cells (AIS), gave the same rate of degradation observed in the soil microcosm (S) (Fig. 5)

Bacterial growth was measured in inoculated microcosms at different incubation times. When the soil microcosms (IS, AIS) were inoculated with high cell density, growth reached the same amount. However, the growth was higher in the microcosm inoculated (AIS) with lower initial cell density ; from an initial density of $6.7 \times 10^{6} \mathrm{cfu} \mathrm{g}^{-1}$ soil the population grew to $1.9 \times 10^{10} \mathrm{cfu} \mathrm{g}^{-1}$ soil after $5 \mathrm{~d}$ of incubation (Table 1). Alcaligenes eutrophus TCP was found to persist at high charge in autoclaved soil (AIS) up to $10 \mathrm{~d}$ from inoculation (around $10^{10} \mathrm{cfu} \mathrm{g}^{-1}$ soil).

\section{DISCUSSION}

A bacterial strain able to grow on 2,4,6-TCP as the unique carbon source was isolated from a selected enrichment culture. The isolate, characterized on the basis of phenotypic and molecular features, was classified as Alc. eutrophus TCP. An Alc. eutrophus JMP 134 (pJP4), originally described for its ability to grow on 2,4 D and other xenobiotics, has been reported to be capable of degrading 2,4,6-TCP without detection of metabolic intermediates (Clément et al. 1995). This degradative capacity seemed not to be related to $\mathrm{pJ} 4$. This strain was also able to degrade CPs when the cells grew on bleached kraft mill effluent (Valenzuela et al. 1997).

The experiments performed in batch show that 2,4,6-TCP is completely degraded with stoichiometric release of chloride anions by the Alc. eutrophus TCP strain. The transient for- 


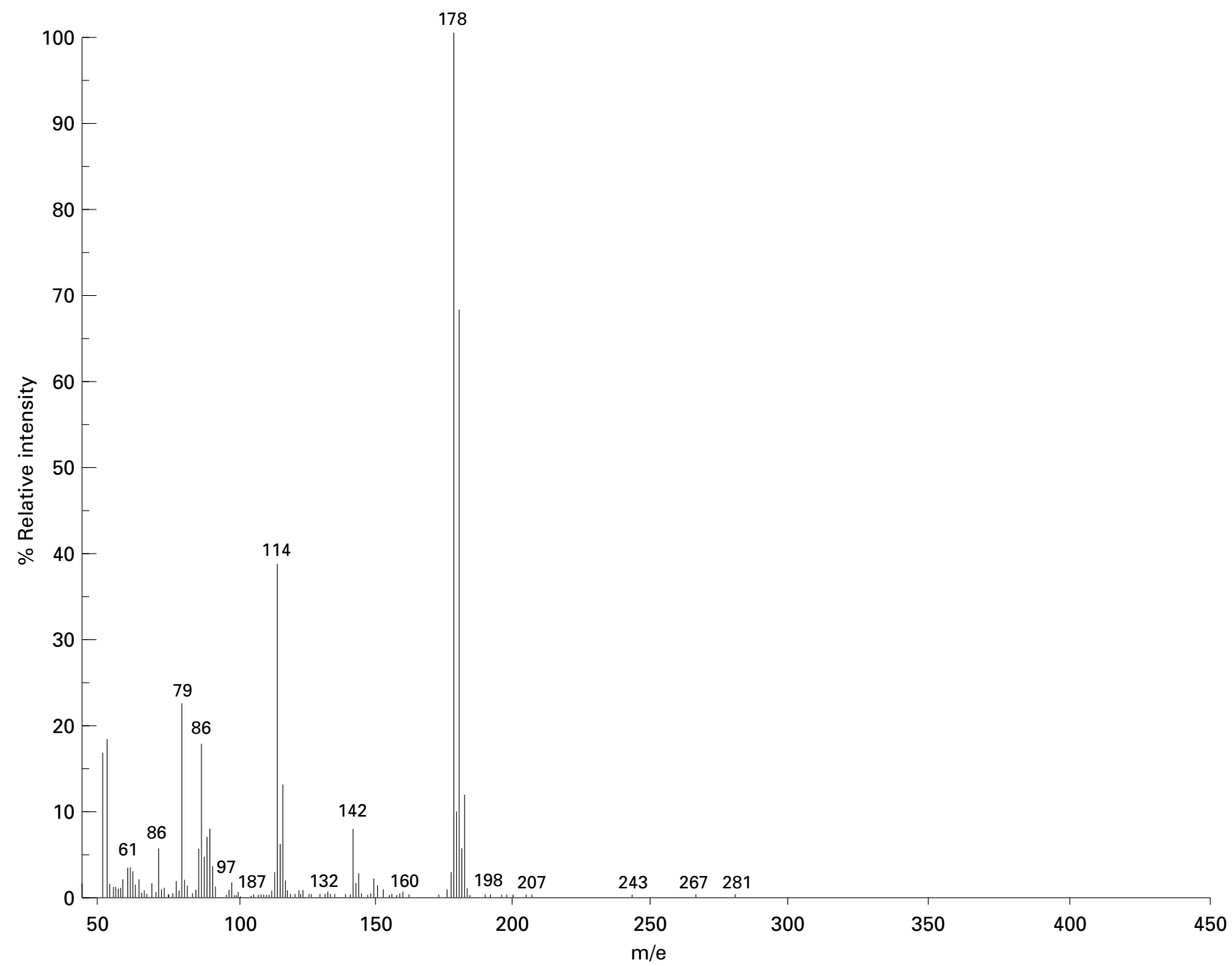

Fig. 4 Mass spectrum of the metabolite isolated from Alcaligenes eutrophus TCP cultures

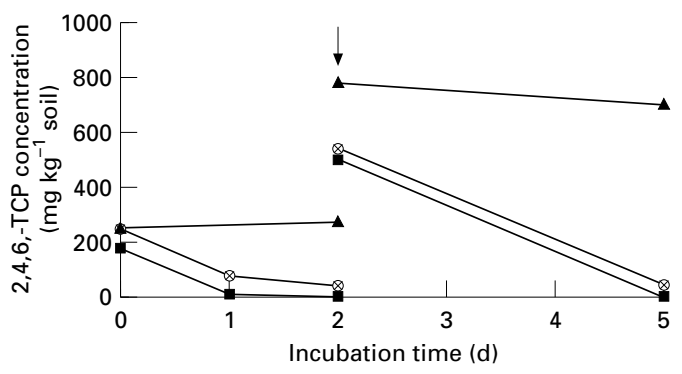

Fig. 5 2,4,6-TCP degradation rate in soil microcosms. $\bigcirc$, soil (S); $\mathbf{\Delta}$, autoclaved soil (AS); $\mathbf{\square}$, inoculated soil (IS); $\times$, autoclaved inoculated soil (AIS). IS and AIS were inoculated with Alcaligenes eutrophus TCP at the same cell density $\left(10^{8} \mathrm{cfu}^{-1}\right.$ soil $)$. Arrow indicates 2,4,6-TCP addition $\left(500 \mathrm{mg} \mathrm{kg}^{-1}\right.$ soil)
Table 1 Microbial growth in soil microcosms containing $250 \mathrm{mg}$ 2,4,6-TCP kg ${ }^{-1}$ soil and inoculated with Alcaligenes eutrophus TCP at different cell densities

\begin{tabular}{lccc}
$\begin{array}{l}\text { Incubation time } \\
\text { (Day) }\end{array}$ & IS & \multicolumn{2}{c}{ AIS } \\
\hline & high density & high density & low density \\
0 & $3 \cdot 8 \times 10^{8}$ & $1 \cdot 8 \times 10^{8}$ & $6.7 \times 10^{6}$ \\
2 & $1.6 \times 10^{9}$ & $1.3 \times 10^{9}$ & $1.1 \times 10^{9}$ \\
5 & $1 \cdot 0 \times 10^{9}$ & $2.6 \times 10^{9}$ & $1.9 \times 10^{10}$
\end{tabular}

IS, Inoculated soil; AIS, autoclaved inoculated soil.

The inoculum was prepared at required cell densities as reported in Materials and Methods. Each count represents the average of two replicates and is expressed as $\mathrm{cfu}^{-1}$ dry soil. 
mation in the microbial culture broths of a dichlorinated dioxygenated metabolite, characterized by mass spectrometry, is in accord with the results of other authors with Pseudomonas and Azotobacter strains (Li et al. 1991 ; Kiyohara et al. 1992). The removal of the chlorine substituent, mostly in para position, by a characterized $p$-hydroxylase to give chlorinated hydroquinones, is retained as the first step in the aerobic degradation of higher chlorinated phenols (from TCPs to PCP) (Tomasi et al. 1995).

Laboratory microcosms inoculated with Alc. eutrophus TCP cells, performed to check whether the strain could be employed for the decontamination of sites polluted with 2,4,6-TCP, showed that: (a) the degradation of 2,4,6-TCP was a biotic process as it did not occur in the autoclaved soil ; (b) 2,4,6TCP was removed at the concentration tested from both inoculated and non-inoculated microcosms at almost comparable rates (however, the slightly lower 2,4,6-TCP degradation rate found in both non-inoculated and autoclaved inoculated soil microcosms with regard to the degradation rate found in inoculated soil microcosm, suggested that autochthonous microflora, able to degrade 2,4,6-TCP, might accelerate the degradative process in the inoculated soil microcosm); (c) the degradative process was accompanied by bacterial growth in all microcosms tested; (d) the inoculum sizes used did not influence the rate of the biodegradative process (data not shown), but affected bacterial growth quantitatively (Table 1) (the concentration of 2,4,6-TCP tested could obviously not adequately support the growth of a population with a high initial density); (e) no competition between indigenous microflora and Alc. eutrophus TCP strain was observed.

In conclusion, the fast removal of 2,4,6-TCP in inoculated microcosms demonstrates that Alc. eutrophus TCP can be used successfully in the remediation of soils contaminated with this zenobiotic. However, the degradability of 2,4,6TCP, biologically mediated, in the soil used in this experimentation, even if not previously treated with chloroorganic pesticides, provides evidence of self-remediability of the contaminated sites, due to the biochemical activities of indigenous micro-organisms. The advantage deriving from this 'selfremediation' is primarily the promptness of the microbial processes which can start as soon as the pollutants are introduced into the environment, as adaptation to the environmental physico-chemical parameters is not required. The assessment of this intrinsic degradative capacity, which can be favoured and accelerated through aeration of the soil, addition of organic nutrients and/or appropriate electron acceptors, allows the adoption of an appropriate remediation strategy. However, the inoculation of contaminated sites with specialized organisms isolated in the laboratory is not always effective as it is strictly dependent on biotic or abiotic stresses (competition with autochtonous micro-organisms, presence of grazing populations, inadequate concentrations of the contaminants etc.).

\section{ACKNOWLEDGEMENTS}

The authors are grateful of Dr R Fasoli for skilful assistance and to Dr G Petruzzelli for providing soil. This work was supported by Fondazione Lombardia per l'Ambiente.

\section{REFERENCES}

Anon. (1987) Notice of the first priority list of hazardous substances that will be the subject of toxicological profiles. Federal Register 52, 12866-12874.

Bock, C., Kroppenstedt, R.M., Schmidt, U. and Diekmann, H. (1996) Degradation of prochloraz and 2,4,6-trichlorophenol by environmental bacterial strains. Applied Microbiology and Biotechnology 45, 257-262.

Christiansen, N. and Ahring, B.K. (1996) Desulfitobacterium hafniense sp. nov., an anaerobic, reductively dechlorinating bacterium. International fournal of Systematic Bacteriology 46, 442-448.

Clément, P., Matus, V., Cárdenas, L. and Gonzales, B. (1995) Degradation of trichlorophenols by Alcaligenes eutrophus JMP 134. FEMS Microbiology Letters 127, 51-55.

Dasappa, S.M. and Loehr, R.C. (1991) Toxicity reduction in contaminated soil bioremediation processes. Water Research 9, 11211130 .

De Lamballerie, X., Zandotti, C., Vignoli, C., Bollet, C. and De Micco, P. (1992) A one step microbial DNA extraction method using "Chelex 100" suitable for gene amplification. Research in Microbiology 143, 785-790.

Doetsch, R.N. (1981) Determinative methods of light microscopy. In Manual of Methods for General Bacteriology ed. Gerhardt, P., Murray, R.G.E., Costilow, R.N. et al. pp. 21-33. Washington, DC: American Society for Microbiology.

Fava, F., Armenante, P.M. and Kafkewitz, D. (1995) Aerobic degradation and dechlorination of 2-chlorophenol, 3-chlorophenol and 4-chlorophenol by a Pseudomonas pickettii strain. Letters in Applied Microbiology 21, 307-312.

Florence, T.M. and Farrar, Y.T. (1971) Spectrophotometric determination of chloride at the parts-per-billion level by the mercury (II) thiocyanate method. Analytica Chemica Acta 54, 373-377.

Häggblom, M.M. and Young, L.Y. (1990) Chlorophenol degradation coupled to sulfate reduction. Applied and Environmental Microbiology 56, 3255-3260.

Huynh, V.B., Chang, H.M., Joyce, T.W. and Kirk, T.K. (1985) Dechlorination of chloro-organics by a white-rot fungus Technical Association of the Pulp and Paper Industry Fournal 68, 98-102.

Hwang, H.M., Hodson, R.E. and Lee, R.F. (1986) Degradation of phenol and chlorophenols by sunlight and microbes in estuarine water. Environmental Science and Technology 20, 1002-1007.

Kiyohara, H., Hatta, T., Ogawa, Y., Kakuda, T., Yokoyama, H. and Takizawa, N. (1992) Isolation of Pseudomonas pickettii strains that degrade 2,4,6-trichlorophenol and their dechlorination of chlorophenols. Applied and Environmental Microbiology 58, 12761283.

Koh, S.C., McCullar, M.V. and Focht, D.D. (1997) Biodegradation of 2,4-dichlorophenol through a distal meta-fission pathway. Applied and Environmental Microbiology. 63, 2054-2057. 
Li, D.Y., Eberspächer, J., Wagner, B., Kuntzer, J. and Lingens, F. (1991) Degradation of 2,4,6-trichlorophenol by Azotobacter sp. strain GP1. Applied and Environmental Microbiology 57, 19201928.

Maniatis, T., Fritch, E.F. and Sambrook, J. (1989) Molecular Cloning : a Laboratory Manual, Vol. 3, 2nd edn. Cold Spring Harbor : Cold Spring Harbor Laboratory Press.

Mohn, W.W. and Kennedy, K.J. (1992) Reductive dehalogenation of chlorophenols by Desulfomonile tiedjei DCB-1. Applied and Environmental Microbiology 58, 1367-1370.

Pritchard, P.H., O’Neill, E.J., Spain, C.M. and Ahem, D.J. (1987) Physical and biological parameters that determine the fate of $p$ chlorophenol in laboratory test systems. Applied and Environmental Microbiology 53, 1833-1838.

Rao, K.R. (1978) Pentachlorophenol: Chemistry, Pharmacology and Environmental Toxicology. New York: Plenum Press.

Rochkind, M.L., Blackburn, J.M. and Sayler, G.S. (1986) Microbial decomposition of chlorinated aromatic compounds. EPA/600/286/090. Cincinnati: US Environmental Protection Agency.

Rohlf, F.J. (1987) NTSYS-pc: numerical taxonomy and multivariate analysis. System for the IBM PC microcomputer (and compatibles), version 1.3. N.Y., USA : Applied Biostatistic Inc.

Sittig, M. (1981) Handbook of Toxic and Hazardous Chemicals. Park Ridge, NJ : Noyes Publications.

Sneath, P.H.A. and Sokal, R.R. (1973) Numerical Taxonomy. San Francisco: W.H. Freeman \& Co.

Sokal, R.R. and Michener, C.D. (1958) A statistical method for evaluating systematic relationship. University of Kansas Science Bulletin 38, 1409-1438.
Steiert, J.G. and Crawford, R.L. (1986) Catabolism of pentachlorophenol by a Flavobacterium sp. Biochemical and Biophysical Research Communications 141, 825-830.

Tomasi, I., Artaud, I., Bertheau, Y. and Mansuy, D. (1995) Metabolism of polychlorinated phenols by Pseudomonas cepacia AC 100 : determination of the first steps and specific inhibitory effect of methimazole. Fournal of Bacteriology 177, 307-311.

Turner Togna, M., Kafkewitz, D. and Armenante, P.M. (1995) Rapid dehalogenation of 2,4,6-trichlorophenol at alkaline $\mathrm{pH}$ by an anaerobic enrichment culture. Letters in Applied Microbiology 20, 113-116.

Utkin, I., Dalton, D.D. and Wiegel, J. (1995) Specificity of reductive dehalogenation of substituted ortho-chlorophenols by Desulfitobacterium dehalogenans JW/IU-DCI. Applied and Environmental Microbiology 61, 346-351.

Valenzuela, J., Bumann, U., Céspedes, R., Padilla, L. and González. (1997). Degradation of chlorophenols by Alcaligenes eutrophus JMP134 (pJP4) in bleached kraft effluent. Applied and Environmental Microbiology 63, 227-232.

Weisburg, W.G., Barns, S.M., Pelletier, D.A. and Lane, D.J. (1991) $16 \mathrm{~S}$ ribosomal DNA for phylogenetic study. Fournal of Bacteriology 173, 697-703.

Wieser, M., Eberspächer, J., Vogler, B. and Lingens, F. (1994) Metabolism of 4-chlorophenol by Azotobacter sp. GP1 : structure of the meta cleavage product of 4-chlorocatechol. FEMS Microbiology Letters 116, 73-78.

Zhang, X. and Wiegel, J. (1990) Sequential anaerobic degradation of 2,4-dichlorophenol in freshwater sediments. Applied and Environmental Microbiology 56, 1119-1127. 